\title{
Moribund enrolment problems of Islamic studies students in Ogun state public secondary schools in Nigeria: Causes and remedies
}

\author{
Salako, Taofiki Ajani*1, Bhasah Abu Bakar², Harison Mohd Sidek ${ }^{2}$ \\ ${ }^{1}$ Tai Solarin University of Education, Ijagun, ${ }^{2}$ Universiti Sains Islam Malaysia
}

Received: 13 February 2018; Accepted: 9 May 2018; Published: 4 June 2018

\begin{abstract}
This paper is aimed to investigate causes of moribund enrolment problems of students in Islamic Studies using Ogun State, Nigeria as a case study. The study focused on 520 students of 42 secondary schools. This included students of Islamic Studies and other Muslim students who did not register for Islamic Studies. Measurement scale was tested using Cronbach's Alpha reliability. This was further subjected to factor analysis for construct and content validity. Researchers thereafter conducted confirmatory factor analysis to establish earlier findings of factor analysis. The study ended with path analysis which the researchers found more robust than multiple regression analysis. Final analysis confirmed five causes of moribund enrolment problems of students in Islamic Studies. Out of these, Job marketability was identified as the main cause which if addressed would solve or reduce the problem to a lower level. Researchers noted however that this could not be achieved without improvement on the Islamic Studies curriculum in use.
\end{abstract}

Keywords: Moribund enrolment, Islamic students, causes and remedies.

\section{Introduction}

Islamic Studies is a subject that is very essential in the pre- and post-primary and secondary levels of education. Globally, it teaches the Islamic fundamentals which are a source of guidance, security and motivation for the child. It teaches the belief in the unity of Allah which serves as a guide and watchdog to his private and public lives. The teaching of Islamic Studies in schools will help to promote better understanding of Islam in the world so as not confuse Islamic principles to terrorist activities and dealings. Its teaching will spell out the role of Muslims in the contemporary world to enable Muslims contribute significantly to world development in the area of using technology for development and reducing human stress as well as in maintaining global peaceful co-existence.

Rammel (2007) describes Islamic Studies a subject of strategic importance which is taught in the national interest to safeguard research and graduates who would have right knowledge, attitude and skills. The teaching of Islamic Studies is to further facilitate the

\footnotetext{
*Email: tasalako@gmail.com; salakota@tasued.edu.ng
} 
teaching and training of future generations to become leading examples of Islamic values and to play an effective role in the present world. Its teaching is to produce experts in all fields to reconstruct world social order and to make the Muslims recover from worldwide moral and spiritual decadence.

With this background knowledge of Islamic Studies in mind, researchers therefore investigated causes of moribund enrolment problems of Islamic Studies students in Ogun State public secondary schools in Nigeria which was becoming a cog in the wheel of achieving the stated tasks.

\section{Background to the study}

The major aim of teaching Islamic Studies is to adequately groom the children of today because they will become the teachers and future leaders of tomorrow with a vision to promoting multiculturalism, economic development, technological advancement and peaceful co-existence. This aim motivated the researchers to investigate causes of moribund enrollment of Islamic Studies students in schools.

\section{Statement of the problem}

It has been observed that the number of students studying Islamic Studies in secondary schools in Nigeria has been decreasing over time. This results in a large number of Muslim students not writing Islamic Studies in their West African examinations. To gain admission into higher education in Nigeria and across the globe requires that an intending student must possess credit pass in the intending course of study in the university. This has therefore affected the admission intakes of students into universities and thereby threatens the future of this subject and more importantly, the job of Islamic Studies teachers has been put on line as a result of this scenario. There is need therefore to forestall this situation and put Islamic Studies on the proper perspective to keep the future of Islam which the subject centres on. The causes of moribund enrolment of students in Islamic Studies therefore forms the focus for this study. Data collected from the selected schools of study confirmed this moribund situation at the senior secondary school level for a period of seven years.

Table 1 and figure 1 below represent the data collected from the selected schools of study in Ogun State, Nigeria. The data show that a larger population of Muslim students study Islamic Studies at the junior secondary school level where the subject is made compulsory but at the senior school level, the subject is optional, as a result a good number of students who studied it at the junior school level dropped it when they get to the senior school level. This data represent a seven year plan with the implementation of the 6-3-3-4 system of education. It therefore shows that because the subject is optional at the senior school level, many Muslim students do not choose it as one of their subjects at this level and perhaps they have a feeling that is has nothing to contribute to their job marketability in the future. 
Journal of Research, Policy \& Practice of Teachers \&

Teacher Education (ISSN 2232-0458/ e-ISSN 2550-1771)

Vol. 8, No. 1, June 2018, 45-62

Table 1. Comparison of junior and senior secondary schools' enrollment figures of Islamic Studies students in Ogun State, Nigeria between 2005 and 2011

\begin{tabular}{|c|c|c|c|c|c|c|c|c|c|c|c|c|c|c|}
\hline Zones & 2005 & & 2006 & & 2007 & & 2008 & & 2009 & & 2010 & & 2011 & \\
\hline & JSS & SSS & JSS & SSS & JSS & SSS & JSS & SSS & JSS & SSS & JSS & SSS & JSS & SS \\
\hline Ijebu & 498 & 139 & 488 & 180 & 448 & 175 & 435 & 191 & 454 & 189 & 446 & 195 & 465 & 213 \\
\hline Remo & 436 & 143 & 464 & 126 & 422 & 141 & 414 & 119 & 378 & 100 & 416 & 120 & 383 & 124 \\
\hline Egba & 461 & 137 & 466 & 137 & 445 & 137 & 456 & 144 & 431 & 140 & 407 & 139 & 403 & 157 \\
\hline $\begin{array}{l}\text { Yewa- } \\
\text { Awori }\end{array}$ & 469 & 136 & 453 & 140 & 449 & 138 & 455 & 143 & 457 & 138 & 447 & 128 & 446 & 147 \\
\hline
\end{tabular}



Figure.1. Graphical relationship of the Islamic Studies students' junior and senior secondary schools' enrolment figures in Ogun State, Nigeria between 2005 and 2011 in the four zones. Note: Blue colour represents the Islamic Studies students' junior schools' enrolment. (High)

Red colour represents the Islamic Studies students' senior schools' enrolment. (Low)

The junior schools' figure is about 301.1 percent (\%) higher than the senior schools' enrolment figure, hence the researchers were interested in why this was so.

(Data gathered from the preliminary inquiries to the schools). 
Table 2. Total enrolment figures of the junior and senior secondary schools' of Islamic Studies students for the four zones of Ogun State, Nigeria between 2005 - 2011.

\begin{tabular}{ccc}
\hline Zones & Junior Sec. Schools & Senior Sec. Schools \\
& & \\
\hline Ijebu & 3234 & 1282 \\
Remo & 2913 & 873 \\
Egba & 3069 & 991 \\
Yewa-Awori & 3176 & 970 \\
Total & 12,392 & 4,116 \\
\hline
\end{tabular}

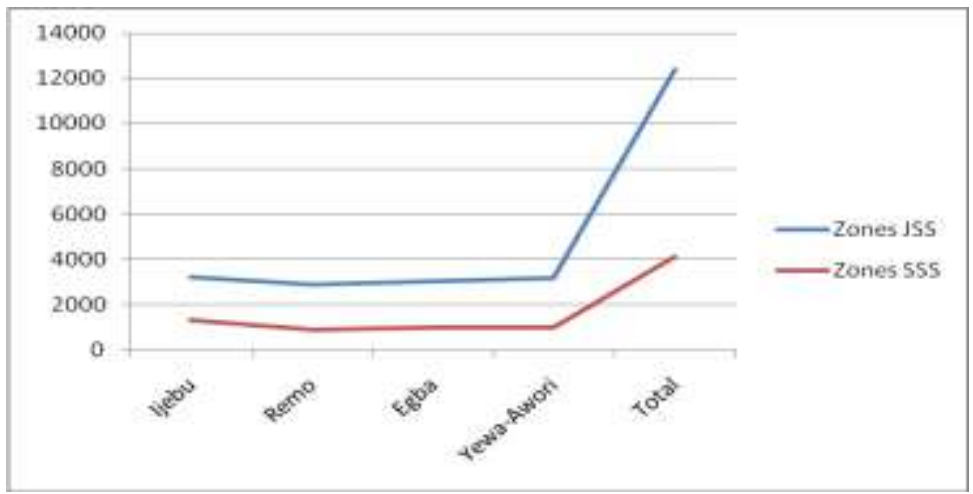

Figure. 2. Total enrollment figures of Islamic Studies students for the four zones of Ogun State,

Nigeria between 2005 and 2011 graphically illustrated.

Note: The graph showed high figures of junior secondary schools Islamic Studies enrolment compared to their senior secondary schools counterparts. These figures were collected through the preliminary inquiries made to the schools through their enrolment register books, results of junior secondary and senior secondary school students in the past seven years. (Data gathered from the preliminary inquiries to the schools).

Table 2 and Figure 2 represent the total summary of the data collected from the zones. Ogun State Nigeria where this study is focused is grouped into four zones. Selected secondary schools in the zones were visited to get preliminary data. The summary of the figures have been put under zones to see at a glance the total number of students who chose Islamic Studies in the junior secondary schools and how the number dropped when the same set of students moved to senior school level. This confirmed that the number of students studying Islamic Studies at the senior school level is dwindling.

\section{Objectives of the study}

The objective of this study was to find out the causes of moribund enrolment problems of students in Islamic Studies and to suggest remedies. Based on this, five research questions were prepared by the researchers.

1. What subjects do most students normally choose at the senior secondary school level?

2. What role does the government policy play in the selection of subjects by the senior secondary school students? 
3. What role does the senior secondary examination bodies play in the choice of subjects of senior secondary school students?

4. What influence do the parents have on the choice of subjects chosen by students at the senior secondary school level?

5. What role does job marketability play on the selection of subjects by the senior secondary school students?

\section{Significance of the study}

The study traced the causes of moribund enrolment problems of students in Islamic Studies and identified the key factor which needed to be addressed to improve the situation.

\section{Literature review}

Rammel (2007) describes Islamic Studies as a subject of strategic importance. By this, it is considered as a subject to be taught in the national interest. It is to be taught to safeguard research, to train graduates who would be equipped with right knowledge, attitudes and skills. It is to be taught to project the role of Muslims in the contemporary world. The Federal Government of Nigeria was aware of this laudable role which could be achieved from the teaching of Islamic Studies and so had categorically stated an objective for religious education in the country which was the inculcation of character and moral training and the development of sound attitudes. (NPE 2004) To effectively achieve this objective, the Federal Government had tasked the states Ministry of Education to produce suitable curriculum and train teachers for the subject. This strategic position of teaching Islamic Studies as a school subject to contribute to world development is illustrated in figure 1, below:

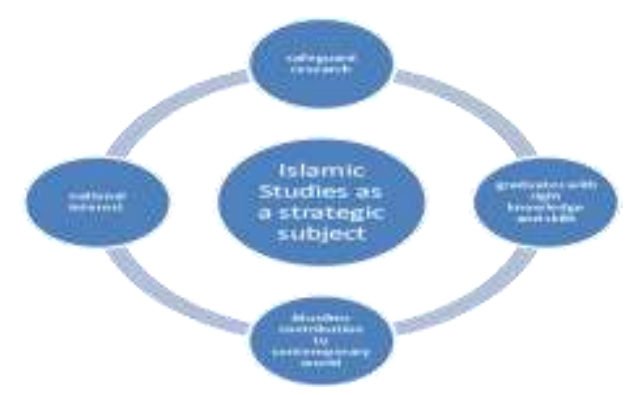

Figure 3. Islamic Studies as a subject of strategic importance

Islamic Studies consists of the study of Islam which encompasses everything from the different branches of Islam like Law, Languages, Medicine, Mathematics, Sciences, History, Geography, Geometry, Chemistry, calculations, politics, economics, personal and interpersonal relationships. This is as interpreted from various Islamic sources including the Qur'an, Haddith, Sunnah and others. With this broad view and expansive topics of studies, students of Islamic Studies are required to be able to research, analyze and interpret varying sources of information in order to arrive at informed conclusions and build their own interpretations. They are also to have analytical and critical thinking skills necessary to 
generate probing theories and questions from time to time to meet the challenges of the contemporary period from the Islamic perspective.

Islamic Studies is the teaching of Islamic religion (Rahim 1992), a religion which protests against idolatry, inequality and evil ways of the society. It is the religion which enjoins its followers to lead a pure, simple and decent life. Abdulati (1990) sees the acquisition of Islamic teachings as total submission to the will of God and obedience to His law.

Bidmos (2008) sees Islamic Education as the acceptance of God to manage man's daily routines which include politics, commerce, legislation, family life, international relations, and prosecution of wars, conflict resolution, inheritance, leisure and using the world to prepare for the hereafter. He posited that it is wrong to restrict Islamic Education to the teaching of worship and prayers alone.

Islamic Studies caters for the spiritual and material aspects of man which could be summarized in the chart below:

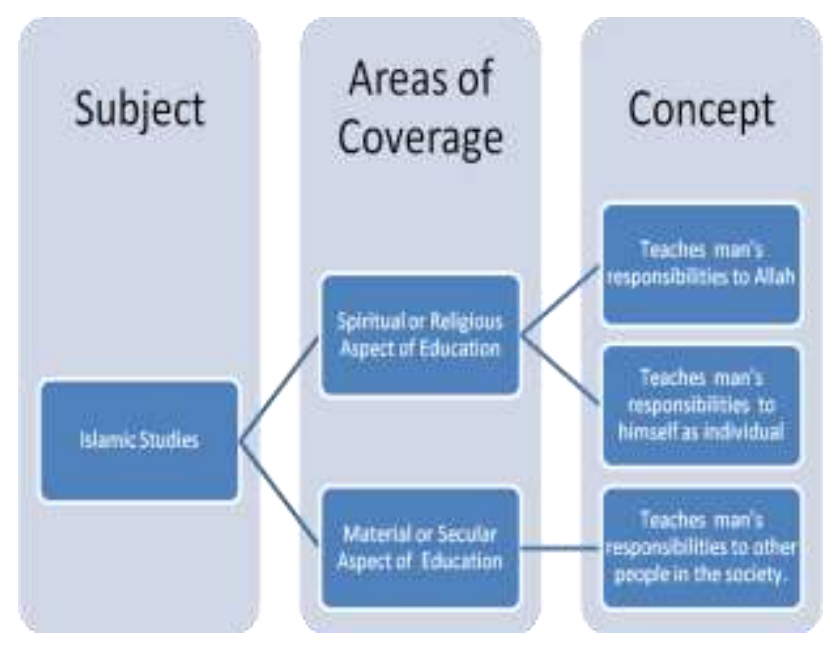

Figure. 4. Concept / meaning and areas of coverage of Islamic Studies

Islamic Studies focuses on the spiritual and material aspects of a man's life. The religious aspect of education regulates the behaviours of man to his Creator, that is to obey Allah's commands, worship Him and move away from what He disapproves. This aspect also regulates man's behaviour to himself, that is to protect the body Allah has given one properly by following His commands in eating what is lawful and avoiding what Allah has described as unlawful.

The secular aspect of education as taught in Islamic Studies is to cater for the sustenance of individual in this world but in the process one should do well and search for his means of livelihood in lawful ways by promoting peaceful co-existence in one's society in particular and in the world in general. Ramadan (2004) points out that people have wrong impression of Islamic studies as they confine it mainly to technical memorization of Quranic verses, prophetic traditions and rules of spirituality. To him, Islamic Studies assists in solving the social and personal problems of the Muslims in an Islamic context. 


\section{Content of Islamic Studies curriculum}

The present curriculum in use for Islamic Studies in Nigeria is as follow and this was prepared around 1984 with the proposed introduction of 6-3-3-4 system of education that fully came into operation in 2004. It was divided into three sections thus:

Hidayah (Guidance)

Section A: The Qur'an

Section B: The Hadith

Section C: $\quad$ Tahdhib (Moral Education)

Fiqh (Islamic Jurisprudence)

Section A: Tawhid (Belief)

Section B: Ibadah (Worship)

Section C: Mu'amalat (Human Transactions) This includes Shariah, Marriage, Divorce, Custody of Children, Inheritance etc.

Tarikh (Historical Development of Islam)

Section A: $\quad$ Sirah (The Life of the Prophet Muhammad) plus the leadership of the 4 Righteous Caliphs

Section B: $\quad$ The Spread of Islam to Western Africa

Section C: $\quad$ Contributions of Muslims to World Civilization.

This curriculum seemed to focus mainly on the spiritual aspect of education. This was due to the fact that Islamic Studies curriculum reviewers at the inception of the 6-3-3-4 structure of education aimed at given students detail and comprehensive information that would enable them practice their religion even if they did not study it at any other level after this stage. It was as if they did not consider creating avenues for Islamic Studies graduates to fill their quota in the labour market. It emphasized spirituality at the expense of secularity and whereas Islamic Studies curriculum was to cater for both spiritual and secular aspects of a man's life.

Saed (2004) lists what he considers to be the content of Islamic Studies as Islamic Fiqh, and Jurisprudence, Islamic history, Islamic Social Laws (including marriage, divorce, contracts and inheritance, Islamic finance, basic tenets and aqeedah of the Islamic faith and tawheed, and Arabic grammar as it relates to the Quran and Islamic texts and so on and so forth. He further adds sciences such as Biology and Chemistry, Crafts and industries and skills like blacksmiths, tailoring and barbing as part of vocations which ought to be learnt in Islamic Studies. Bidmos (2003) on the other expresses the view that Islamic Studies no matter what it teaches should involve moral education.

Buhari (2007, p.15,) quoting Opeloye defines Islamic Studies as:

"a body of knowledge arising from the Quran as revealed to Muhammad which blossomed into its various branches during the period of Ummayad and saw full light in the reign of the Abbasid. This field of learning covers Literature, Religion, Sciences as well as Natural Science". Rahim (1992) described the Arab Islamic scholars as the torch- bearers of civilization and culture in the Middle Age. Among the Muslim contributors and periods when they excelled were Khawarizmi, a great Mathematician (750-850 A.D), Ibn - Sina excelled in Medicine, Jabir ibn Hayyan was famous in Chemistry (776 A.D)

A rich curriculum of any subject Islamic Studies inclusive should prepare students for all round and holistic development whereby the students would be useful to themselves and the society in which they belong. The Federal Government of Nigeria apart from tasking 
the states Ministry of Education to produce suitable curriculum and train teachers for Islamic Studies as a subject in addition introduced a new policy on education to revolutionize the Nigerian educational system and to tailor her education towards scientific and technological advancement in order to meet the needs of Nigerians in the contemporary world. The new policy brought about the categorization of subjects into core and elective. Consequently, Islamic Studies was grouped among elective subjects at the senior secondary school level. Also, because of the emphasis on scientific and technological advancement, the policy apportioned $60 \%$ to studying of courses in favour of Sciences while $40 \%$ was for the Humanities and Management Sciences to share. (NPE 2004). This led to a mad rush on the part of the students generally from Arts based subjects to the sciences because majority of the students following the introduction of this policy wanted to become scientists, engineers and the likes and so majority abandoned Arts subjects among which Islamic Studies is now grouped.

\section{Location of the study}

The research was limited to some selected public secondary schools i.e. those owned by the Ogun state government, Nigeria and two semi-private secondary schools which were the Olabisi Onabanjo University International School, Ago-Iwoye and the Tai Solarin University of Education Secondary School, Ijebu-ode.

\section{Research methodology}

Random sampling technique was used in this study. Forty two (42) secondary schools were randomly selected for the study in the four zones of Ogun State, Nigeria. Students studying Islamic Studies and other Muslim students who did not choose Islamic Studies as a subject in the senior secondary class 3 were involved in the study. This was the level at which the moribund enrolment in Islamic Studies was much felt.

A self-prepared Questionnaire by the researchers was used. This was given to research experts to vet. This was divided into two sections; section A contained the demographic information which included age, sex, religion, parents' religious background etc. Section B carried 30 item questions on moribund enrolment of students in Islamic Studies. Researchers used closed ended questions with multiple choice options from SD - Strongly Disagree to SA - Strongly Agree.

A 5 - Likert scale was used to get data from the respondents. Researchers adopted the five Likert scale because the use of odd scale as observed by Rensis Likert (1932) was said to be most commonly used by researchers. Brian $\mathrm{Hu}$ (2010), pointed out that the 4 - point scale tended to over- scale the answers going to the extreme values more than the 5-point Likert scale. It had also been observed that the 4-point Likert scale might exaggerate the answers arrived at. In this way, this might as well have survey biases and tend to satisfy the researchers' opinions and views. Coakes \& Steed (2001) and Pallant (2010) too supported this assertion.

\section{Analysis}

A total of 520 students were given questionnaires to fill. Students' demographic information revealed that 504 students fully responded to the questionnaire. Out of this figure, 500 students $(99.2 \%)$ were admitted into the schools from Junior secondary school one, 4 students $(0.79 \%)$ were admitted into the schools from senior secondary school one and two. 476 of the students $(94.4 \%)$ were in senior secondary school 3 i.e the final year for secondary school education 
while only 28 candidates $(5.6 \%)$ were in the senior secondary two. This study concentrated on the senior secondary school three students who were supposed to write their final secondary school examinations. All these students being Muslims in majority attempted Islamic Studies in their junior secondary school and even when the records showed that they had passed in their junior secondary school examinations, a large number of them dropped the subject when they got to senior secondary school class three when they were to write final senior secondary school examinations.

As per the age range of the students, $86(17.1 \%)$ were between 9 and 14 years of age while the remaining $418(82.9 \%)$ of them were between the age range of 15 to 18 years. As for their gender, 221 of the students involved in this study $(43.8 \%)$ were males and the rest $283(56.2 \%)$ were females. Students religion showed that $490(97.2 \%)$ were Muslims and the rest $13(2.61 \%)$ were Christians as indicated on the demographic data except for one candidate $(.2 \%)$ who did not indicate his religion.

Students fathers' religion indicated that $488(96.8 \%)$ had their fathers' religion as Islam, while $14(2.8 \%)$ of them indicated that their fathers were Christians and 2 of them (.2\%) did not indicate their fathers' religion. On the other hand $465(92.3 \%)$ of the students indicated that their mothers were Muslims while $39(7.7 \%)$ of them showed that their mothers were Christians. Out of the 504 students involved in this study, $108(21.4 \%)$ registered for Islamic Studies in their senior final year class examinations while a large percentage of them $396(78.6 \%)$ did not register for it in their final year examinations.

\section{Reliability of data}

Cronbach's Alpha reliability test used to examine internal consistencies of the items involved in the instrument showed the coefficient of .91. The value of the test ranged between 0 to 1 , when 0 means zero reliability while 1 means complete reliability. Thirty (30) item questions were prepared in the questionnaire to test the variables, subject choice, government policy, WAEC / NECO role, parents' influence and role of job marketability. The value of .91 recorded made the data very significant and thus valid and reliable having met the recommended acceptable levels.

\section{Construct and content validity of data}

Component factor analysis was used to extract variables that were really responsible for causes of moribund enrollment problems. This was to also ensure that the questions on the questionnaires were not misunderstood by the students. Therefore, Principal Component Analysis was used to reduce the many variables to smaller ones that had direct influence on the causes. Consequently, the data results recorded a Kaiser-Meyer-Olkin Measure of Sampling Adequacy (KMO) of .91 while Bartlett's Test of Sphericity recorded a p value of .000. This instrument satisfied the acceptable condition of (KMO) and (BTS) for analysis and further discussions. The result is presented in table 6 below:

Table 3. Measure of sampling adequacy

\begin{tabular}{ll}
\hline Kaiser- Meyer -Olkin Measure of Sampling Adequacy. & .910 \\
Bartlett's Test of Sphericity df. & 435 \\
Sig. & .000 \\
\hline
\end{tabular}

The communality recorded for individual items ranged between .6 and .8 with some of the items below .6. The eigenvalue was above 1 with 6 items giving a cumulative percentage 
of 53.05 loading on $.50(50 \%)$. Also, the anti-image correlations of all the items were above .3 , ranging between .6 and .9. This statistical result for anti-image, communality and eigenvalues is presented in table 4 as follow:

Table 4. Anti-image correlation, communalities and eigenvalues of students' data

\begin{tabular}{|c|c|c|c|c|c|}
\hline $\mathrm{S} / \mathrm{N}$ & Items. & $\begin{array}{l}\text { Cronbach } \\
\text { Reliability }\end{array}$ & $\begin{array}{l}\text { Anti- } \\
\text { image }\end{array}$ & $\begin{array}{l}\text { Commu- } \\
\text { nality }\end{array}$ & $\begin{array}{l}\text { Eigen- } \\
\text { value }\end{array}$ \\
\hline 1 & I prefer Islamic Studies than other subjects. & .90 & .95 & .76 & 9.10 \\
\hline 2 & Parent's demands encourage study Islamic Studies in the school. & .90 & .95 & .72 & 1.70 \\
\hline 3 & Islamic Studies is related to my future course of study. & .91 & .96 & .63 & 1.47 \\
\hline 4 & Islamic Studies is to learn about my religion. & .91 & .94 & .72 & 1.28 \\
\hline 5 & Students choose Islamic Studies as the last option. & .91 & .84 & .41 & 1.20 \\
\hline 6 & Islamic Studies is meant for Arts students alone. & .91 & .86 & .50 & 1.14 \\
\hline 7 & I choose Islamic Studies in SS III. & .91 & .97 & .41 & .99 \\
\hline 8 & $\begin{array}{l}\text { Science and Commercial students are opportuned to offer } \\
\text { Islamic Studies in SSS } 3 .\end{array}$ & .91 & .88 & .54 & .92 \\
\hline 9 & $\begin{array}{l}\text { Arts students register for Islamic Studies in Senior Certificate } \\
\text { Examinations. }\end{array}$ & .91 & .89 & .40 & .87 \\
\hline 10 & $\begin{array}{l}\text { Islamic Studies is on the school time-table for science and } \\
\text { commercial students. }\end{array}$ & .91 & .83 & .60 & .84 \\
\hline 11 & $\begin{array}{l}\text { SSS III students to choose Islamic Studies in West African } \\
\text { Examinations Council. }\end{array}$ & .91 & .95 & .50 & .80 \\
\hline 12 & Islamic Studies teacher focus more on religious teachings. & .91 & .96 & .50 & .73 \\
\hline 13 & Islamic Studies is encouraged by WAEC and NECO guidelines. & .91 & .91 & .62 & .73 \\
\hline 14 & $\begin{array}{l}\text { Schools encourage students to register for Islamic Studies in } \\
\text { WAEC and NECO examinations. }\end{array}$ & .91 & .93 & .60 & .66 \\
\hline 15 & $\begin{array}{l}\text { Islamic Studies is important in WAEC and NECO } \\
\text { examinations. }\end{array}$ & .91 & .96 & .44 & .63 \\
\hline 16 & Islamic Studies is necessary for University admission in Nigeria. & .91 & .94 & .45 & .62 \\
\hline 17 & I need Islamic Studies in my future course of study. & .91 & .93 & .50 & .59 \\
\hline 18 & $\begin{array}{l}\text { Status of Islamic Studies on WAEC and NECO encourage } \\
\text { students to register for it in senior certificate examinations. }\end{array}$ & .91 & .95 & .40 & .58 \\
\hline 19 & Parents encourage students to choose Islamic Studies in SS III. & .91 & .96 & .50 & .56 \\
\hline 20 & My parent wants me to be a scientist / engineer. & .91 & 63 & .60 & .55 \\
\hline 21 & My parent wants me to be an economist / business man. & .91 & 60 & .60 & .52 \\
\hline 22 & My parent wants me to be a teacher. & .91 & .91 & .50 & .50 \\
\hline 23 & $\begin{array}{l}\text { My parent organizes extra coaching for me at home on Islamic } \\
\text { Studies. }\end{array}$ & .91 & .97 & .32 & .46 \\
\hline 24 & $\begin{array}{l}\text { My parent bothers more on my other school subjects than } \\
\text { Islamic Studies. }\end{array}$ & .91 & .91 & .52 & .44 \\
\hline 25 & Islamic Studies graduates get employed in teaching. & .91 & .95 & .50 & .42 \\
\hline 26 & $\begin{array}{l}\text { Islamic Studies graduates get employed in banking industry, } \\
\text { factories and companies. }\end{array}$ & .91 & .95 & .60 & .38 \\
\hline 27 & $\begin{array}{l}\text { Graduates of Islamic Studies get employed faster than graduates } \\
\text { of other subjects. }\end{array}$ & .91 & .94 & .61 & .36 \\
\hline 28 & $\begin{array}{l}\text { Employment opportunities are available for Islamic Studies } \\
\text { graduates. }\end{array}$ & .91 & .95 & .54 & .32 \\
\hline 29 & $\begin{array}{l}\text { Advertisements for employment opportunities favour Islamic } \\
\text { Studies graduates. }\end{array}$ & .91 & .95 & .62 & .27 \\
\hline 30 & $\begin{array}{l}\text { Scholarship and sponsorship opportunities are avai1lable to } \\
\text { Islamic Studies students. }\end{array}$ & .91 & .95 & .53 & .24 \\
\hline
\end{tabular}

Using the rule of thumb, rotated matrix with Kaiser Normalization of the varimax showed that 18 items contributed significantly to the causes which were responsible for moribund enrollment problems of Islamic Studies students. The acceptable level for eigenvalue is 1 according to researchers. Hence, the PCA yielded good result with eigenvalue of 1, the degree of inter-correlation among items reached the acceptable level of 1 since the ranges of scores in this study are above 1.09 and to 4.57 . The eigenvalue is hereby accepted 
having met the approved standard. The Rotated Component Matrix was conducted. Consequently, eighteen (18) items were finally extracted. Items 1, 2, 3, 4, measured choice of subject selection. Items 8 and 10 measured the variable government policy. Items 11, 14, 15, and 16 measured the variable WAEC and NECO influence. Item 21 and 22 measured the variable parents' role. Items 25, 26, 27, 28, 29 and 30 measured the variable role of job marketability which was the main variable. The six items met the conditions stipulated for anti-image, communalities, and eigenvalues loading on 90 percent and above 50 percent respectively.

\section{Confirmatory Factor Analysis (CFA)}

Researchers further employed the use of confirmatory factor analysis to confirm the scale of measurement used in the research. Hair et al. (1998) suggested that Confirmatory Factor Analysis (CFA) should be employed to investigate quality of each individual item before the items should be combined in summated analysis. Confirmatory factor analysis produces many goodness-of-fit measures to evaluate the model but do not calculate factor scores according to Brown (2006). The standard of acceptable conditions and areas of measures in confirmatory factor analysis as recommended by experts like Hu \& Bentler (1999), Schumacker \& Lomax (2004), Brown (2006), Anglim (2007), Jeremy, Albright \& Hun Myoung Park (2009), and others to determine the significant levels of test results are model fit, parameter estimates and Tucker Lewis Index and model indices to mention a few.

In this study, the researchers used EQS (Structural Equation Modeling Programme Software) developed by Joreskog et al (1976) to conduct the confirmatory factor analysis. Eighteen (18) items were extracted with the use of factor analysis from the total 30 items in the scale of measurement. The Chi square recorded $=205.864(125 \mathrm{df}), \mathrm{P}$ value $=.000$, the GFI $=.956$, the AGFI $=.940$, the CFI $=.974$, The TLI $=.968$ and the RMSEA $=.036$. The analysis identified five causes which were subject choice, government policy, WAEC influence, parents' role and the role of job marketability.

There is correlation among all the four variables with students' choice of subject selection which is the dependent variable at varying degree levels. While job marketability has high correlation of .73 with registration for WAEC and NECO examinations, it has .75 for choice of subject selection. Job marketability recorded .40 correlations with parents and .44 correlations with government policy. This portrays that the four variables have influence on the choice of subject. However, it was noted that the influence of job marketability and registration for external examinations like WAEC and NECO were higher. Confirmatory factor analysis (CFA) further confirmed that students generally avoid the study of Islamic Studies because job security is of utmost importance to them and this is backed up by their parents who would want their children get employed after leaving school. The confirmatory factor analysis of students' result is presented below in figure 5 . 


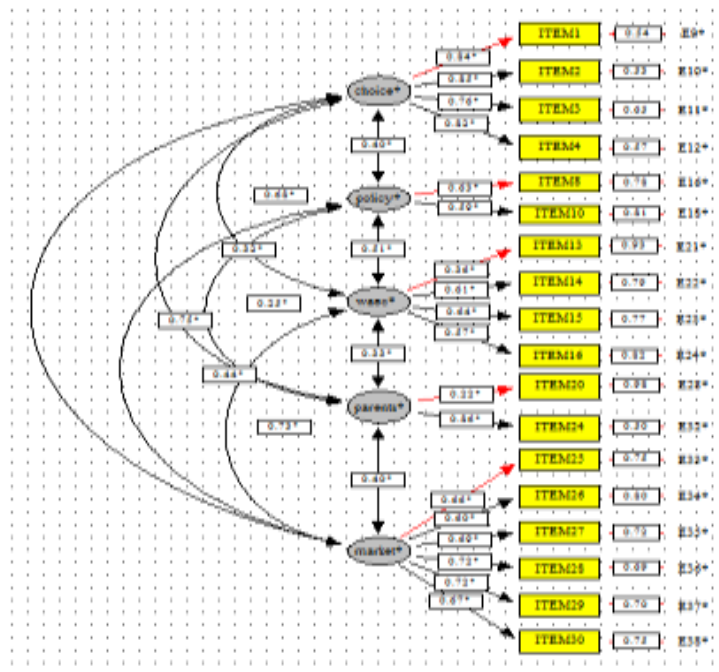

Figure 5. Confirmatory Factor Analysis (Path Diagram)

Having satisfied all the ideal conditions of CFA set by the experts, the researchers of this study thereafter employed the used of path analysis. This is because the multiple regressions is not robust enough to measure errors and models misspecification. Path analysis explains more roles than a relational model. This includes explaining the direct and indirect effects of the measured variable on the latent variable.

\section{Path Analysis}

Results of the path analysis model indicated a chi - square of 2.477 , P value of .000 , the NFI of 0.995 , the NNFI of 0.972 the GFI recorded was .998, the AGFI recorded was .971 , the CFI recorded was .998 , The TLI was .972 and the RMSEA recorded was .054. This data satisfied the acceptable conditions for path analysis and met all the parameters for path analysis model testing. Path model analysis is presented below in figure 6 .

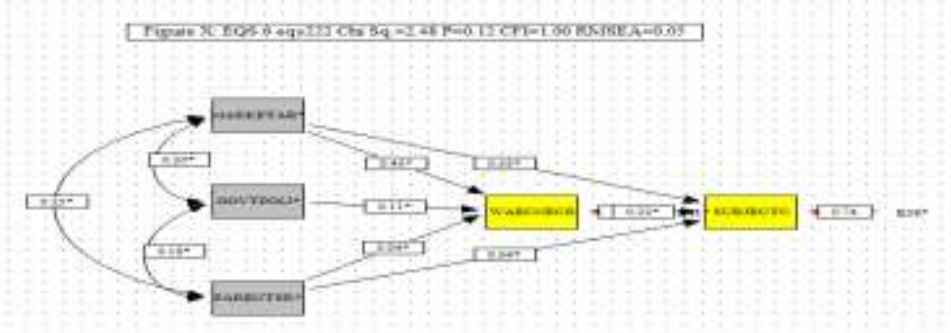

Figure 6. Path Model 
Path analysis model retained all the five variables hypothesized by the researchers to be responsible for moribund enrollment problems of students in Islamic Studies. This model showed correlations between the job marketability and government policy on one hand and between government policy and parents on the other hand and vice versa. In addition, these three variables job marketability, government policy and parents had direct influence on Waec I Neco registration on one hand while two of them job marketability and parents also had direct influence on the students' choice of subject selection.

\section{Research findings}

The findings suggested that the relationship between job marketability and parental choice was both direct and indirect relationships. The analysis found that marketability $(\mathrm{r}=.53, \mathrm{p}$ $=.001)$ and parental choice $(\mathrm{r}=.04, \mathrm{p}=.05)$ had direct correlation with subject choice which indicated that these two factors were key in propelling students' choice as to what subjects to choose or not. Job marketability and parents influence also have indirect relationship with students' choice of subject through WAEC examinations $(\mathrm{r}=.14, \mathrm{p}=.001),(\mathrm{r}=.43, \mathrm{p}=.001)$ respectively. The government policy however did not have direct relationship with students' enrollment but through WAEC $(\mathrm{r}=.11, \mathrm{p}=.05)$

The finding established job marketability as the major cause of moribund enrollment of students in Islamic Studies. Parents are influenced by the policy on the subject that would fetch their children job after leaving school. What the students are after and which would propel them to choose any subject in the secondary school and university is any course of study which could guarantee them job security. The way Islamic Studies is being taught in Nigeria today, the subject may not be able to meet this need and hence the reason why students are not willing to study the subject and the number of students' enrollment keep decreasing. This also has implications on the teaching and practice of Islam as a religion which could as well affect moral behavior of graduates in the society. Further implications of this finding have been answered in the research questions which all centred on job marketability, job security and future long live sustenance.

\section{Response to Research Question 1 \\ What subjects do most students normally choose at the senior secondary school level?}

The Nigerian educational policy provides $60 \%$ quota for the science and technological education while $40 \%$ quota is earmarked for the humanities and social sciences. (NPE 2004) In addition, the same educational policy categorized the subjects into compulsory and elective statuses at the senior secondary school level. This development had made the students to aspire to choose subjects in the sciences and commercial areas. Consequently, students normally prefer to choose subjects labelled compulsory while running away from those not under compulsory status. Unfortunately however, Islamic Studies is not among the compulsory subjects and hence students prefer to choose compulsory subjects. This has been one of the major causes for moribund enrollment of students in Islamic Studies at the senior secondary school level. 


\section{Research Question 2 \\ What role does the government policy play in the selection of subjects by senior secondary school students?}

Government of any nation plays a significant role in the educational policies, structures and systems of a nation. Government made some subjects compulsory and others elective. Government also classified subjects into three groups namely sciences, commercial and arts. (NPE 2004) More recognition has been given to sciences and commercial subjects in lieu of arts subjects. As a result, because students wanted recognition and because they would want to be associated with government likings, they preferred to choose those subjects which would give them this recognition and make them wanted by the government. This development has consequently affected the enrollment figures of students of Islamic Studies because it has not been grouped among the core subjects given high recognition by the government and the people in the society. Islamic Studies is not favoured by the Nigerian government policy and does not suit the choice of students in the senior class level where they have been given the option of whether to choose it or not as attested to by other researches. (Lawal 2003, NERDC 2012, Azeez \& Adeshina 2013)

\section{Research Question 3 \\ What role does the senior secondary examinations bodies play on the choice of subjects by senior secondary school students?}

The recognized senior secondary school examinations bodies in Nigeria are West African Examinations Council (WAEC) and National Examinations Council (NECO). The first, WAEC has a coverage of some West African countries while the latter; NECO has a coverage within Nigeria. The role played by these examination bodies on the choice of subject was highly significant. The significance of WAEC / NECO registration was felt in the path model analysis which reflected that this element had direct relationship with subject choice selection.

Registration for WAEC / NECO examinations is of paramount importance to senior secondary school students because their performance in these examinations would determine their future carrier and their hopes for securing admission into the universities. Asides, students wanted to be associated with attractive courses in the university. Among these attractive courses, Islamic Studies is not one of them. Therefore, students did not want to enroll for Islamic Studies in the senior certificate examinations for the fear that it would deny them of registering for more attractive subjects. As a general requirement for university admission in Nigeria and as it is the practice throughout the world, a student is to possess a credit pass in the senior certificate examinations in his proposed university course of study. Therefore, if students did not register for Islamic Studies in the senior certificate examinations as it had been established in this study, it would be difficult for them to study it in the university.

These examination bodies categorically stated some subjects that would be considered before they could issue out certificates to students. Islamic Studies was not among the subjects listed. This no doubt had negative effect on the psyche of the students who were forced to choose some subjects which could make them get certificates from these examination bodies. They had no option than to drop Islamic Studies because they had limited number of subjects to choose in the senior secondary final year examinations.

By this analysis, there was an indication that WAEC / NECO examination bodies contributed to the choice of students not registering for Islamic Studies at the senior secondary school level. Hence the more reason why the number of students who offer Islamic Studies at the senior secondary school level has kept decreasing over time. 


\section{Research Question 4 \\ What influence do the parents have on the choice of subjects chosen by students at the senior secondary school level?}

Reflections from path analysis indicted that parents played a significant role on the choice of subjects chosen by their children in the senior secondary school examinations. From the analysis, parents had direct influence on students' WAEC / NECO registrations and at the same time direct influence on choice of subject selection by students at the senior class level. Government policy and job marketability had direct influence on the parents which was an indication that parents would consider the future of their children before advising them on the subjects to choose at the senior secondary school level. Parents were the financers of their children's education and as such their opinion on choice of subject to choose would have effect on the choice of subject selected by students. There is a proverbs that says, "He who pays the tune dictates the piper" indicating that parents who sponsor their children education would have influence on the choice of subjects their wards would choose to satisfy their parents who had been influenced by the by government educational policies and future prosperity (Maududi nd, Rosnani 2007, Nordin 2012).

\section{Research Question 5}

\section{What role does job marketability play on the selection of subjects by senior secondary school students?}

Today, the ultimate goal of any educational objective or skill acquisition is to create employment opportunities for the trainee. This has been the trend the world over. (Anour 1981, Dean 2005, Rosnani 2007, Azra 2011, Lik 2011) Gone were the days when an individual or group participated in a programme for the fun of it. The same development now applies to education and the end product of any form of education acquired these days is to find one a good job which could secure one's source of livelihood and guarantee the future.

The policy of education in Nigeria and across board is now based on this. This policy however favoured some subjects above the others. The fear of the future and the hope of securing good employments was a propelling force for determining the choice of subjects students would choose at the senior secondary school level because this is the level which would determine the future as far as they were concerned.

\section{Conclusion}

Path analysis employed in this study recognized job marketability as a strong variable. The analysis resulted in job marketability having direct influence on registration for WAEC and NECO examinations. This was the more reason why the students' choice of subject had been tailored to choosing subjects that would fetch them job. Also, job marketability again had direct influence on the choice of subject. To students, Islamic Studies was not among these subjects which could meet their yearnings and aspirations and so the more reason why they had not registered for it in the senior secondary school examinations and why they could not study it in the university. Job marketability played a very significant role in the choice of subject chosen by students. The study further established the fact that the teaching curriculum of Islamic Studies presently lacked the contents that could make it marketable for students studying the subject. (Haji Alias et al 2007, Owoyemi 2009). Among all the variables, job marketability was the most influential cause as suggested by the findings and analysis. 


\section{Suggestions}

The proactive step to correcting the moribund enrolment of students in Islamic Studies is to review the present curriculum in use for this subject. The proposed curriculum should be expanded to accommodate entrepreneurial studies. It should also include topics like Murabahah, Mudarabah, Musharakah, Ijarah, Takaful, Sukuk and other Islamic business transactions which could make Islamic Studies graduates function well in today's Islamic Banks and Islamic financial institutions. This proposition is supported by Kayadibi, Saim (2010) and others. This would make Islamic Studies graduates readily fill the vacuum which exists for experts in Islamic financial theories and it will enhance their job marketability without necessarily compromising Islamic teachings and practices.

\section{References}

Abdallati, H. (1990). Islam in Focus. International Islamic Federation of Student Organization. n.pb.

Albright, J. J., \& Park, H. M. (2009). Confirmatory Factor Analysis using Amos, LISREL, Mplus, SAS/STAT CALIS. University Information Technology Services, Center for Statistical and Mathematical Computing, Indiana University. http://www.indiana.edu/ statmath assessed 10/10/2013.

Anglim, J. (2007). "Structural Equation Modelling." 325-711 Research Methods. http://jeromyanglim.googlepages.com/ assessed on $2^{\text {nd }}$ November 2013.

Azeez, A. O., \& Adeshina, S. T. (2013). Islamic studies in Nigeria: Problems and prospects. International Journal of Humanities and Social Science. Vol. 3 No. 2 [Special Issue - January 2013]

Azra, A. (2011). From IAIN to UIN: Islamic Studies in Indonesia. Islamic studies and Islamic education in contemporary Southeast Asia (ed.) Kamaruzzaman, B. A., Patrick, J. Yayasan Ilmuwan, D-0-3A, Setiawangsa Business Suites, Taman Setiawangsa, 54200 Kuala Lumpur, Malaysia.

Bidmos, M. A. (2008). Utilizing the Potentials of Islamic Education in Nation Building. University of lagos Innuagural Lecture Series. University of Lagos Press, Unilag P.O Box 132, University of Lagos, Akoka, Yaba-Lagos, Nigeria.

Brian, Hu. (2012). Likert Scale: 4-point v. 5-points? Overseas Chinese Association for Institutional Research. Users/Public/Documents/Likert-4-scale.htm. assessed 30/11/2012.

Brown, T. A. (2006). Confirmatory Factor Analysis for Applied Research. The Guilford Press, New York, London.

Coakes, S. J., \& Steed, L. G. (2001). SPSS Analysis without Anguish. John Wiley \& Sons Australia, Ltd.

Dean, B. L. (2005). Citizenship education in Pakistani schools: Problems and possibilities. International Journal of Citizenship and Teacher Education, 1(2), 35-55.

Federal Government of Nigeria. (2014). National Policy on Education $4^{\text {th }}$ edition. (NPE 2014) Federal Ministry of Education.

Ibrahim, A. B. (2011). Islamic studies and Islamic education in contemporary Southeast Asia. (ed.). Kamaruzzaman, B. A., Patrick. J. Yayasan Ilmuwan, D-0-3A, Setiawangsa Business Suites, Taman Setiawangsa, 54200 Kuala Lumpur, Malaysia

Kamal, H. (2011). Islamic studies and Islamic education in contemporary Southeast Asia. (ed.). Kamaruzzaman, B. A., Patrick, J. Yayasan Ilmuwan, D-0-3A, Setiawangsa Business Suites, Taman Setiawangsa, 54200 Kuala Lumpur, Malaysia 
Kayadibi, S. (2010). Employability and marketability of the graduates of Islamic studies in Islamic banking and finance: Malaysian experience. Journal of Islamic Law Studies (IHAD), 16 (16). pp. 503-516.

Lawal, M. A. (2011). The state of Islamic education in South-Western Nigeria. Al-Ijitihad, the journal of the Islamization of Knowledge and Contemporary Issues. Vol.9. No.1, Kano, The International Institute of Islamic Thought

Lik, A. M. (2011). Maintaining Religious Tradition in Brunei Darussalam: Inspiration and Challenges. Islamic studies and Islamic education in contemporary Southeast Asia. (ed.). Kamaruzzaman, B. A., Patrick, J., Yayasan Ilmuwan, D-0-3A, Setiawangsa Business Suites, Taman Setiawangsa, 54200 Kuala Lumpur, Malaysia

Likert, R. (1902). The Origin of Likert Scales. Notes on Likert Scales. (comp) Stanley. L. S. 2001. /Users/Public/Documents/likert-6.htm. assessed 16/02/2013.

Majid, A. (1981). "Quixotic Quest: In Pursuit of Islam". The State of Islamic Studies in American Universities. (ed.). The International Institute of Islamic Thought. 1431AH/2009CE. The international institute of Islamic thought. P.O. Box 669, Herndon, Va 20172, USA, www.iiit.org

Mawdudi Abul Al'a (nd). www.islamawareness.net/Education/importance.html,assessed on $3 / 10 / 2012$

Mohammad, H. A., Zurina, K., \& Nursilah A. (2007). Employability of Islamic Studies Graduates in Malaysia. Universiti Sains Islam Malaysia, Nilai.

National Examinations Council (NECO) Nigeria. (2002). Regulations and Syllabuses for Senior Secondary Certificate Examination (SSCE), For School Candidates (2002 -2004). National Examinations Council, Minna, Nigeria.

National Curriculum for Junior Secondary Schools for Social Science and Religion. (2005). Fed. Ministry of Education, Nigeria

Nigerian Educational Research and Development Council (NERDC) Revised 2012. NREDC Printing Press. Yaba, Lagos, Nigeria

Nordin, K. (2012). Marketability of graduates churned out by universities should stretch beyond geographical borders. The Malaysian Insider, Saturday 8, December 2012.

Opeloye, M. A, (2007). (ed.). Al-Hadarah. LASU Journal of Arabic \& Islamic Studies. Vol.7. Department of Religions, Lagos State University Ojo, Nigeria.

Owoyemi, A. A. (2009). Small Scale Entrepreneurship and Poverty Alleviation among the Muslims in Ijebuland. Guest Lecture. Al-Hayat Relief Foundation $2^{\text {nd }}$ National General Meeting. Held on $21^{\text {st }}$ June, 2009 at OGD Hall, Tai Solarin University of Education, Ijagun, Ijebu-ode, Ogun State, Nigeria.

Pallant, J. (2010). SPSS Survival Manual - A step by step guide to data analysis using SPSS program $4^{\text {th }}$ edition. Allen \& Unwin Book Publishers, Australia.

Rahim A, (1992). Islamic History. Islamic Publications Bureau, 136A, Isolo Road, Mushin, Lagos, Nigeria, West Africa

Ramadan, T. (2004). Western Muslim and the Future of Islam. Oxford; New York: Oxford University Press.

Rammell, B. (2007). Islamic Studies: Definition and the Methodology employed in teaching it. www.informaworld.com/smpp/content

Rosnani, H. (2007). Intellectualism in higher Islamic traditional studies: Implications for the curriculum. The American Journal of Islamic Social Sciences 24:3

Saed, A. M. (2003). Islam Volume 13, Character Morals: Questions \& Answers. London, U.K. MSA Publication Ltd.

Saed, A. M. (2003). Islamic Questions and Answers. Volume 11. Knowledge Publication. London, U.K. MSA, Publication Ltd. 
Schumacker, R. E., \& Lomax, R. G. (2004). A beginner's Guide to Structural Equation Modeling. Lawrence Erlbaum associates, Publishers. Mahwah, New Jersey, London. USA.

Wright, S. J. (1921). Correlation and causation. Agricultural Research 20: 557585.en. wikipedia.org/w/index.php?title=Pathanalysis(statistics)\&oldid=573894 76. Assessed on $2^{\text {nd }}$ November 2013 